ISSN: 1410-8917

Jurnal Kimia

Sains \&

Aplikasi

e-ISSN: 2597-9914
Jurnal Kimia Sains dan Aplikasi 23 (6) (2020): 222-227

Jurnal Kimia Sains dan Aplikasi Journal of Scientific and Applied Chemistry

Journal homepage: http://ejournal.undip.ac.id/index.php/ksa

\title{
Utilization of Montmorillonite-Modified Earthenware from Bentonite-Ca as a Microbial Fuel Cell (MFC) Membrane Based on Tempe Liquid Waste as a Substrate
}

\author{
Sudarlin ${ }^{\text {a,* }}$, Andika Wahyu Afrianto ${ }^{a}$, Melly Khoerunnisa ${ }^{a}$, Dhea Wiegya Rahmadhani \\ a, Anggit Nugroho ${ }^{a}$ \\ a Department of Chemistry, Faculty of Science and Technology, Universitas Islam Negeri Sunan Kalijaga, Sleman, Yogyakarta, \\ Indonesia \\ * Corresponding author: sudarlin@uin-suka.ac.id \\ https://doi.org/10.14710/jksa.23.6.222-227
}

Article Info

Article history:

Received: $11^{\text {th }}$ February 2020

Revised: $10^{\text {th }}$ April 2020

Accepted: $26^{\text {th }}$ April 2020

Online: $30^{\text {th }}$ June 2020

Keywords:

current; power density;

proton transfer; redox

reaction; potential

difference

\section{Abstract}

Modifications of the Microbial Fuel Cell (MFC) membrane need to be carried out to increase its electric potential energy. This research aims to determine the effect of montmorillonite from bentonite-Ca as a composite in modified earthenware (GT), which is then used as a membrane of the MFC-based on tempe wastewater as substrate. The results obtained were compared to MFC that used pure earthenware membrane (GM). The ratio of bentonite-Ca and clay in GT was 50:50, while GM used $100 \%$ of clay. Characterizations of GT dan GM were performed using FTIR, $\mathrm{XRD}$, and SAA. MFC testing was carried out for 24 hours, where every 2 hours, measurements of potential difference $(\mathrm{V})$, current $(\mathrm{A})$, and power density $\left(\mathrm{W} / \mathrm{cm}^{2}\right)$ were carried out. FTIR and XRD data showed an increase in montmorillonite content in GT, while SAA data showed a decrease in pore volume in GT. The decrease in pore volume GT occurs due to an increase in the number of trivalent cations ( $\mathrm{Al}^{3+}, \mathrm{Fe}^{3+}$ ) and bivalent $\left(\mathrm{Mg}^{2+}\right)$. These cations help transfer protons from the anode to the cathode, which causes a decrease in the potential difference and an increase in the current and the MFC-GT power density. The average difference between the decrease in potential difference from MFC-GM to MFC-GT is $0.043 \mathrm{~V}$, while the increase in current is $0.022 \mathrm{~mA}$, and the increase in power density is $0.163 \mathrm{~mW} / \mathrm{cm}^{2}$.

\section{Introduction}

Microbial Fuel Cell (MFC) is an alternative energy system that utilizes organic matter with microorganisms to produce electrical energy [1]. Various studies have been conducted to improve the performance of MFC. The research was conducted on the electrode, reactor design, type of bacteria, membrane, and substrate used [2].

For the type of membrane used, one that has been successfully developed and produced on an industrial scale is the Proton Exchange Membrane (PEM) such as Nafion 117, Nafion 424, and Nafion 551WX. However, water in the anode vessel makes PEM use less efficient and easily damaged because water can directly deliver protons to the cathode, resulting in a reduction in electrical energy. Besides, the costs required for the production of this membrane are relatively expensive [3].

To overcome this problem, alternative MFC membranes that can be used are clay membranes, such as ceramics or earthenware. Winfield et al. [4] state that ceramics are more stable in proton transfer and provide a safer environment for microorganisms' metabolism. Ceramics in MFC technology can be used as waste containers, ion exchange media, and MFC electrodes.

In another research, Winfield et al. [5] using earthenware as an ion exchange media. The waste used is synthetic waste in a single chamber reactor. The results obtained indicate a high-power density of 3660 $\mathrm{mW} / \mathrm{m}^{2}$. The weakness of using pure earthenware in this study is its relatively short operating time, which is only six weeks. 
The use of pottery as an MFC membrane has also been carried out by Andika and Sudarlin [6], which uses tempe liquid waste as a substrate. The results obtained show a reasonably high-power density of 2197.343 $\mathrm{mW} / \mathrm{m}^{2}$. The disadvantage is the same as in the study of Winfield et al. [4, 5], in which the relatively short operational time at which a decrease in power density occurs at the $14^{\text {th }}$ hour [6].

Different things are found if the earthenware used is montmorillonite ceramics. Research of Ghadge et al. [7], which uses montmorillonite as a membrane in the dual-chamber MFC, can achieve an operating time of up to 8 weeks with a higher power density of $7550 \mathrm{~mW} / \mathrm{m}^{2}$. In other studies, the more montmorillonite content used, the higher the density of power produced [8]. However, the use of montmorillonite is inefficient for the MFC system because the operating temperature is quite high, which is $32^{\circ} \mathrm{C}$ higher than pure earthenware, whose operating temperature is only $24^{\circ} \mathrm{C}$. If it reaches a high temperature, waste in the MFC system must be recycled because microorganisms cannot last long.

The weaknesses of pure clay earthenware and pure montmorillonite ceramics can be overcome using a composite method between pure earthenware and montmorillonite. Therefore, the earthenware produced is montmorillonite modified earthenware. Uddin [9] reported that clay could be compiled with montmorillonite to nano size. Similar research results were also published by Li and Peng [10], who made composites from $\mathrm{MoSe}_{2}$ soil types with montmorillonite for the decomposition of rhodamine dye waste. These two studies show that pure clay and montmorillonite can produce stable earthenware composites in the moist environment of the MFC system.

Related to the waste that can be used, the tempe industry is one source of waste in the form of tempe liquid waste. Water is widely used in the process of soaking and boiling soybeans. As a result, the contents of carbohydrates, proteins, fats, and acids will be dissolved in the wastewater. The wastewater is generally disposed of in rivers or waterways. Waste in waterways causes environmental problems such as foul odor and reduction of oxygen levels in sewer water.

The utilization of tempe liquid waste as a substrate in the MFC system has been conducted by Luthfiah and Artsanti [11] using a dual-chamber MFC with a cation exchanger in the form of a salt bridge and graphite carbon electrodes. Tempe liquid waste substrate in the system is capable of producing a power density of 6296 $\mathrm{mW} / \mathrm{m}^{2}$ in control waste, $5719 \mathrm{~mW} / \mathrm{m}^{2}$ in waste with $2 \%$ glucose addition, and $4 \%$ glucose obtained the highest value of $5856 \mathrm{~mW} / \mathrm{m}^{2}$. The COD value in the controlled waste decreased by $1.52 \%$, in the substrate with the addition of glucose $2 \%$ and $4 \%$ decreased by $9.76 \%$ and $9.64 \%$, respectively.

The ability of earthenware as an ion exchange media based on the results of research by Winfield et al. [5] and its chance to be modified as a composite with montmorillonite based on the results of Ghadge et al. [7] and Li and Peng [10] as well as increasing the MFC power density using tempe liquid waste and decreasing the COD content of waste based on the results of the Luthfiah and Artsanti [11] can be combined to improve the efficiency of MFC as the objective of this study. In this study, the membrane used is a composite in the form of montmorillonite modified earthenware (GT) and compared with pure earthenware from brown clay (GM). Montmorillonite used is montmorillonite as the main mineral in Ca-bentonite. The parameters studied in this study are the effectiveness of proton transfer between GT and GM in the form of potential difference (V), current $(\mathrm{A})$, and power density $\left(\mathrm{mW} / \mathrm{m}^{2}\right)$.

\section{Methodology}

The research process includes designing the device (MFC chamber), manufacturing earthenware, electrode preparation, substrate preparation, and running the MFC. The details of the tools and materials needed and the stages of the research are detailed as follows:

\subsection{Tools and Materials}

The instrument used in this study is the dualchamber MFC reactor with anode and cathode chamber separated by a membrane in the form of earthenware, as presented in Figure 1. Other tools used include glassware, volumetric pipettes, cuvettes, claws, cables, waste containers, sterile plastic bottles, turntables, refrigerators, Aditeg A-830 digital multimeters, Shimadzu Prestige-21 Fourier Transform-Infra Red (FTIR), Shimadzu 6000-Elmer X-Ray Diffractometer (XRD), and Quantachrome Surface Area Analyzer (SAA).

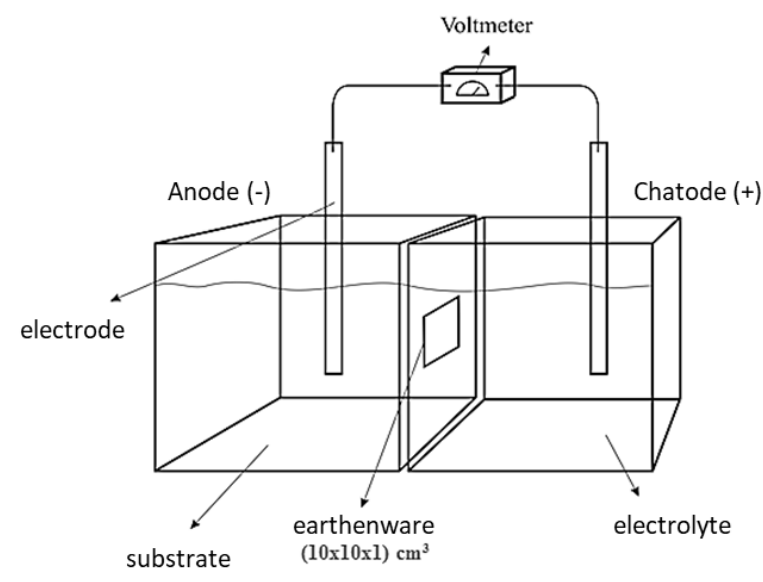

Figure 1. Schematic design of a double chamber MFC using an earthenware membrane

The material used in this research was tempe liquid waste from $\mathrm{Hj}$ Tukiran Tempe Industry Jl. Pandean Yogyakarta, brown clay loam from Kasongan Bantul, bentonite-Ca from Pacitan, graphite carbon rod size 29.5 $\mathrm{cm}^{2}, 1 \mathrm{M} \mathrm{HCl}$ solution (Merck), practical grade (PA), $1 \mathrm{M}$ $\mathrm{NaOH}$ solution (Merck) p.a, distilled water, alcohol 70\% technical grade, and $\mathrm{KMnO}_{4} 0.1 \mathrm{M}$ Merck solution p.a.

\subsection{Manufacturing Earthenware}

Earthenware was made from brown clay using a throwing technique. Modified earthenware (GT) was added by bentonite-Ca at a ratio of 50:50, while pure earthenware (GM) used $100 \%$ clay. Earthenware was in 
the form of $10 \times 10 \times 1 \mathrm{~cm}^{3}$ plates, and two plates each were made. One plate was used for MFC membranes, and the rest was used for XRD, FTIR, and SAA characterization.

\subsection{Electrode Preparation}

The electrodes used were graphite carbon bars with a surface area of $29.5 \mathrm{~cm}^{2}$. Before use, the electrodes were first cleaned and activated. Graphite sticks were immersed in $1 \mathrm{M} \mathrm{HCl}$ solution and $1 \mathrm{M} \mathrm{NaOH}$ each for 24 hours. After that, the electrodes were stored in containers containing distilled water until they were used.

\subsection{Waste Substrate Preparation}

Tempe liquid waste was obtained directly from the Hj Tukiran Tempe Industrial waste Jl. Pandean Yogyakarta. Waste was put into sterile $1 \mathrm{~L}$ plastic bottles. Previously, plastic bottles were sterilized using 70\% alcohol. Waste was taken by dipping a sterile plastic bottle directly into a waste collection container. Before being analyzed, the waste sample was stored in a refrigerator at $4^{\circ} \mathrm{C}$.

\subsection{Running MFC}

Anode vessel was filled with tempe liquid waste substrate as much as $900 \mathrm{~mL}$. Meanwhile, the cathode vessel was filled with $900 \mathrm{~mL}$ of $\mathrm{KMnO}_{4} 0.1 \mathrm{M}$ electrolyte solution. The two graphite carbon electrodes were connected to a digital multimeter. MFC reactors run for 24 hours. Measurement of current and the potential difference was conducted every 2 hours using a digital multimeter.

\section{Results and Discussion}

\subsection{Earthenware Characterization}

The results of X-Ray Diffraction (XRD) characterization are presented in Figure 2 in the form of pure earthenware (GM) diffractogram and modified earthenware (GT). The results show a value of $2 \ominus$ at $26.9^{\circ}$ $(d=3.31 \AA)$, following JCPDS standards No.13-0259, i.e., $d=3.34 \AA$ is a montmorillonite mineral. The increase in basal spacing from $2 \theta=26.6^{\circ}$ in GM to $2 \theta=26.9^{\circ}$ in GT indicates an increase in montmorillonite content. This increase is linear, with an increase in Ca-bentonite quartz intensity due to an increase in the number of $\mathrm{Si}-$ O-Si bonds [12].

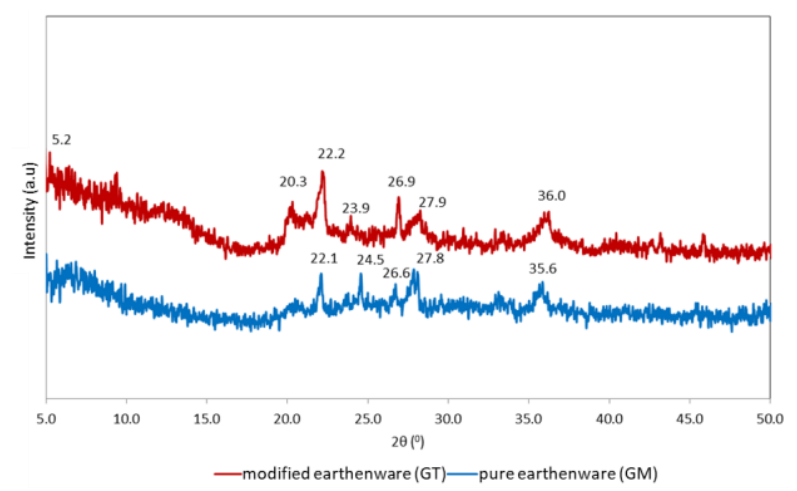

Figure 2. XRD diffractogram of pure earthenware (GM) and modified earthenware (GT)
The increased montmorillonite presence in GT is also shown by $2 \theta=5.2^{\circ}(d=16.85 \AA)$, according to JCPDS No.13-0135, i.e., $d_{001}=15.00 \AA$ is a montmorillonite mineral. Other mineral is indicated by peaks of $2 \theta=22.2^{\circ}$ $(d=4.01 \AA)$, according to JCPDS No.11-0695, i.e., $d_{101}=$ $4.05 \AA$ which is a cristobalite mineral [13]. High intensity indicates higher levels of cristobalite in GT.

Peak $2 \theta=20.3^{\circ}(d=4.37 \AA)$ in accordance with JCPDS No. $05-0490$, i.e., $d_{100}=4.26 \AA$ is a quartz mineral. This mineral is a mineral contained in GT but not in GM. Other minerals found in both earthenware are illit which is shown at three different peaks, i.e., at $2 \theta=23.9^{\circ}$, $27.9^{\circ}$, and $36.0^{\circ}$ for $\mathrm{GT}$, and $2 \theta=24.5^{\circ}, 27,8^{\circ}$, and $35.6^{\circ}$ for GM. The data is in accordance with JCPDS No.240495 and JCPDS No.26-0911. The difference in the value of $2 \ominus$ between GT and GM is due to differences in the metamorphic epizone mineral illit properties in both [14].

The high content of montmorillonite and cristobalite in GT can enhance the earthenware cation exchangeability as an MFC membrane [15]. The increase in montmorillonite content was confirmed by FTIR characterization, as presented in Figure 3. Increased absorption intensity $1056.9 \mathrm{~cm}^{-1}$ indicates an increase in montmorillonite intensity in GT. The absorption and absorption of $1064.7 \mathrm{~cm}^{-1}$ in $\mathrm{GM}$ are the buckling vibrations of Si-O. The absorption of $\mathrm{Si}-\mathrm{O}-\mathrm{Si}$ buckling strengthens the presence of $\mathrm{Si}-\mathrm{O}$ groups at $470.6 \mathrm{~cm}^{-1}$ [16]. The sharper absorption of GT shows that the Si-OSi environment is increasingly homogeneous, supported by a peak shift from $1064.7 \mathrm{~cm}^{-1}$ in GM and to $1056.9 \mathrm{~cm}^{-}$ ${ }^{1}$ in GT [12].

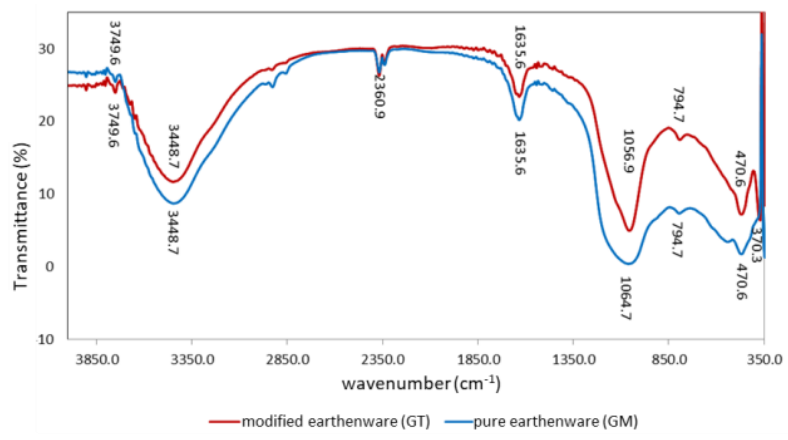

Figure 3. FTIR spectra of pure earthenware (GM) and modified earthenware (GT)

The absorption at 3749.6 and $3448.7 \mathrm{~cm}^{-1}$ shows the stretching vibrations of $\mathrm{OH}$ (hydroxyl groups bound to $\mathrm{Al}$ in the octahedral layer $\mathrm{Al}-\mathrm{Al}-\mathrm{OH}$ or $\mathrm{Mg}-\mathrm{OH}-\mathrm{Al}$ ). The absorption band reinforces this at wave number 1635.6 $\mathrm{cm}^{-1}$, which shows the bending vibration of $\mathrm{H}-\mathrm{O}-\mathrm{H}$ water adsorbed on Ca-bentonite. Another group observed was $\mathrm{Fe}^{3+}-\mathrm{OH}-\mathrm{Mg}$ at wave number $794.7 \mathrm{~cm}^{-1}$ with low intensity. This data shows that modified earthenware (GT) is rich in trivalent ions $\left(\mathrm{Al}^{3+}, \mathrm{Fe}^{3+}\right)$ and bivalent $\left(\mathrm{Mg}^{2+}\right)$ [17].

Overall the FTIR characterization results showed an increase in montmorillonite content in GT. Also, there was absorption in the fingerprint area at $370 \mathrm{~cm}^{-1}$, a characteristic of montmorillonite smectite dioctahedral 
absorption. This absorption shows the high content of $\mathrm{Al}^{3+}$ and $\mathrm{Mg}^{2+}$ ions in GT [18].

The increase in montmorillonite material in GT is supported by an area based on SAA (Surface Area Analyzer) data, as presented in Table 1. The SAA results using the BET method both single point and multipoint indicate that the GT area is wider than the GM area. In contrast, GM pore volume is higher than the GT pore volume. This proves that the GT pore has been filled with trivalent cations $\left(\mathrm{Al}^{3+}, \mathrm{Fe}^{3+}\right)$ and bivalent $\left(\mathrm{Mg}^{2+}\right)$, ready to be exchanged with MFC protons.

Table 1. Area and pore volume of pure earthenware (GM) and modified earthenware (GT)

\begin{tabular}{cccc}
\hline Parameter & Method & $\begin{array}{c}\text { Pure } \\
\text { earthenware }\end{array}$ & $\begin{array}{c}\text { Modified } \\
\text { earthenware }\end{array}$ \\
\hline $\begin{array}{c}\text { Surface area } \\
\left(\mathrm{m}^{2} / \mathrm{g}\right)\end{array}$ & $\begin{array}{c}\text { Single } \\
\text { Point BET } \\
\text { MultiPoint } \\
\text { BET }\end{array}$ & 39.55 & 44.88 \\
& BJH & 0.173 & 46.34 \\
$\begin{array}{c}\text { Pore volume } \\
\left(\mathrm{cm}^{3} / \mathrm{g}\right)\end{array}$ & $\begin{array}{c}\text { B } \\
\text { M }\end{array}$ & & 0.165 \\
\hline
\end{tabular}

\subsection{Electric Potential}

A comparison of the potential difference $(\mathrm{V})$ and current (I) of MFC based on pure earthenware (MFC$\mathrm{GM}$ ) and modified earthenware (MFC-GT) is presented in Figures 4 and 5. The results obtained indicate that the potential difference in MFC-GM is higher than MFC-GT. This is due to the transfer of protons in the form of $\mathrm{H}_{3} \mathrm{O}^{+}$ from the anode to the cathode on MFC-GT aided by the exchange of montmorillonite cations.

The presence of trivalent cations $\left(\mathrm{Al}^{3+}, \mathrm{Fe}^{3+}\right)$ and bivalent $\left(\mathrm{Mg}^{2+}\right)$ of montmorillonite, which is more in GT, helps the proton exchange; hence it diffuses faster to the cathode and does not accumulate at the anode. The cation exchange involves the interaction of $\mathrm{OH}$ groups in montmorillonite with $\mathrm{H}_{3} \mathrm{O}^{+}$ions [19]. If the protons accumulate at the anode, the potential difference in the system will increase. Conversely, the rapid transfer of protons from the anode to the cathode will reduce the potential difference between the anode and the cathode [7]. This happens because a large number of protons in the cathode will accelerate the reduction of $\mathrm{MnO}_{4}^{-}$ according to the reaction $\mathrm{MnO}_{4}^{-}+4 \mathrm{H}^{+}+3 \mathrm{e}^{-} \rightarrow \mathrm{MnO}_{2}+$ $2 \mathrm{H}_{2} \mathrm{O}$. As a result, the concentration of $\mathrm{MnO}_{4}{ }^{-}$at the cathode gets smaller, so the potential at the cathode gets bigger according to the Nernst equation:

$$
E=E^{o}-\frac{R T}{n F} \ln \frac{\left[\mathrm{MnO}_{2}\right]}{\left[\mathrm{MnO}_{4}^{-}\right]}
$$

The higher the cathode potential reduces the potential difference between the anode and the cathode [20]. The average difference in the decrease in potential difference from MFC-GM to MFC-GT in this study is $0.043 \mathrm{~V}$.

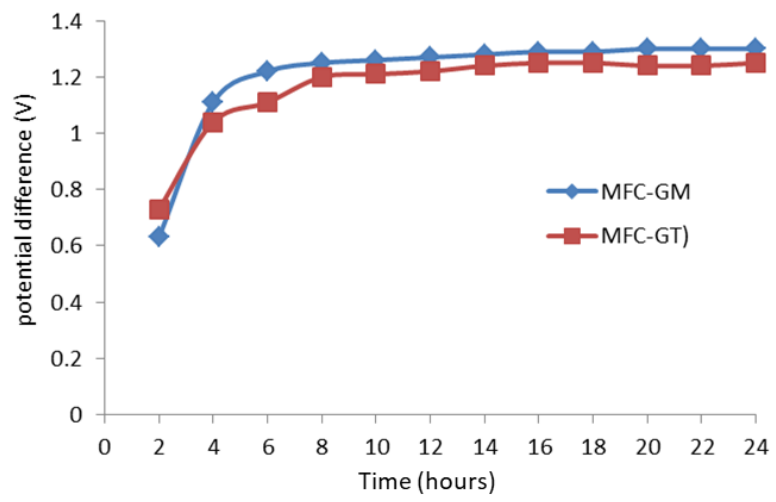

Figure 4. Comparison of the potential difference between pure earthenware-based MFCs (MFC-GM) and modified earthenware (MFC-GT)

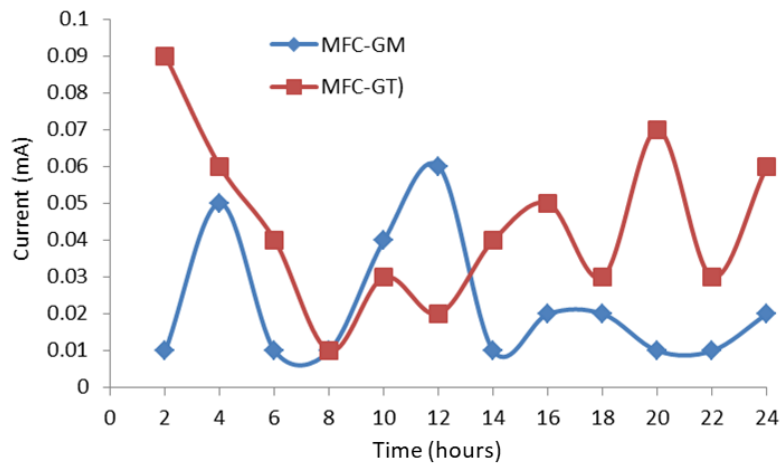

Figure 5. Comparison of currents in MFC based on pure earthenware (MFC-GM) and modified earthenware

(MFC-GT)

The faster reduction reaction at the cathode causes the flow of electrons through the external circuit to accelerate; thus, the current system increases [7]. Another factor that increases currents is montmorillonite's ability to prevent oxygen diffusion from the cathode to the anode making the reduction reaction at the cathode occurs more fully [8]. As presented in Figure 5, the current data shows that MFCGT currents are higher than MFC-GM, with an average increase of $0.022 \mathrm{~mA}$.

Related to operational time, which is 24 hours, the potential difference produced by MFC-GM and MFC-GT starts to be constant at the 6th hour, which is in the range of $1.2-1.3 \mathrm{~V}$. This corresponds to the stationary phase of the bacteria [20]. This phase causes proton transfer from the anode to the static cathode so that there is no change in the potential difference. However, this research still needs to be continued until the time variations indicate the phase of bacterial death to decrease each MFC's potential difference.

Meanwhile, the time variation on the current measurement shows stable data after the 14th hour, where the current MFC-GT is consistently higher than the current MFC-GM. Current before the 14th hour shows unstable data, although on average, MFC-GT current is still higher, at $0.044 \mathrm{~mA}$ compared to 0.022 $\mathrm{mA}$. This shows that many factors influence the transfer of electrons from bacteria to the anode, external circuits, 
the cathode, and finally, to the catholyte in the MFC system.

One of the influencing factors is the type of electrode used. The use of graphite bars as electrodes at the anode triggers the formation of $E$. coli biofilms on the surface of the graphite [21]. As a result, graphite electrodes will be covered by $E$. coli biofilms so that the electron transfer only comes from E. coli by direct transfer [22]. This condition prevents the transfer of electrons from other bacteria so that the strong current of the MFC system begins to stabilize at the $14^{\text {th }}$ hour, where the MFC-GT current is higher than the MFC-GM current. That is, the current of the MFC system is only influenced by the type of membrane used. The current is no longer affected by the competition of bacterial electron transfer to the electrode, which causes the current to be inconsistent before the $14^{\text {th }}$ hour. Bacteria that can grow in tempeh and tofu waste are Escherichia coli, Saccharomycopsis fibuligera [23], Bacteroides, Bifidobacterium, Clostridium, Lactobacillus, and Streptococcus [24].

The conclusions generated based on the above data show that the addition of bentonite rich in montmorillonite to GT can increase the cation in earthenware pores. The existence of these cations helps proton diffusion so that the transfer of protons from the anode to the cathode becomes faster. The proton transfer rate is proportional to the current produced. Thus, the use of a montmorillonite modified earthenware membrane from Ca-bentonite is quite efficient in increasing the MFC's electrical potential. The increase is based on the power density $\left(\mathrm{mW} / \mathrm{cm}^{2}\right)$ produced, as presented in Figure 6, i.e., the average MFC-GT power is consistently higher, especially after the 14th hour with an average increase of $0.163 \mathrm{~mW} / \mathrm{cm}^{2}$. The power density curve pattern is the same as the current curve described earlier.

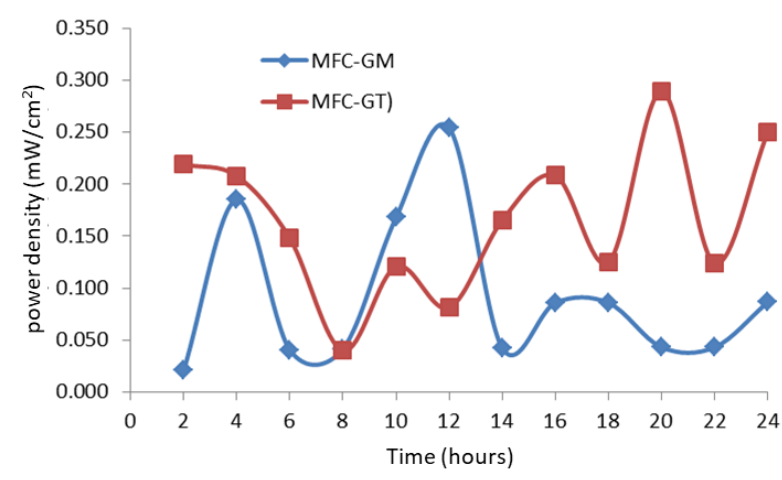

Figure 6. Comparison of power density in pure earthenware-based MFCs (MFC-GM) and modified earthenware (MFC-GT)

In addition to biofilm formation factors on graphite electrodes at the anode, current and power density as the data in Figures 5 and 6 are also influenced by the formation of $\mathrm{MnO}_{2}$ layers on the surface of graphite electrodes at the cathode [25]. In MFC-GM, the formation of the $\mathrm{MnO}_{2}$ layer is so significant that the surface of the graphite electrode at the cathode is closed. As a result, the current and power density dropped significantly at the $14^{\text {th }}$ hour. Meanwhile, in the MFC-
GT, the formation of the $\mathrm{MnO}_{2}$ layer is still in the initiation stage so that the current and power density produced remains high. This research needs to be continued for a longer time variation, to show a decrease in current and power density on the MFC-GT.

Bacterial growth at the anode is also a factor that influences the current and power density of the MFC. Rapid bacterial growth will increase the density of bacteria at the anode, thereby inhibiting electron transfer to the anode [26]. As a result, electrons passing through the external circuit are reduced to decrease the MFC's current and power density. These conditions occur in this study. Based on the data in Figures 5 and 6 , there is a similar pattern of data due to the formation of the $\mathrm{MnO} 2$ layer as previously described. Based on existing data patterns, GT's use as an MFC membrane can reduce the influence of the $\mathrm{MnO} 2$ layer and increase bacterial density so that current and power density remain high.

\section{Conclusions}

The results of FTIR and XRD characteristics showed an increase in montmorillonite content in GT. SAA characterization shows that the pore volume of GT is smaller because it is filled with trivalent cations $\left(\mathrm{Al}^{3+}\right.$, $\left.\mathrm{Fe}^{3+}\right)$ and bivalent $\left(\mathrm{Mg}^{2+}\right)$. These cations help the transfer of protons from the anode to the cathode, which causes a decrease in the potential difference and an increase in the current and power density of the MFC-GT. The average difference between the decrease in potential difference from MFC-GM to MFC-GT is $0.043 \mathrm{~V}$, while the increase in current is $0.022 \mathrm{~mA}$, and the increase in power density is $0.163 \mathrm{~mW} / \mathrm{cm}^{2}$.

\section{Acknowledgment}

The authors thank the Lembaga Penelitian dan Pengabdian Masyarakat (LP2M) UIN Sunan Kalijaga Yogyakarta for the funding and technical research guidance through Program Bantuan Dana Penelitian Dasar Pengembangan Prodi 2019 based on SK No. 106.11 tahun 2019.

\section{References}

[1] Peter Aelterman, Korneel Rabaey, Hai The Pham, Nico Boon, Willy Verstraete, Continuous Electricity Generation at High Voltages and Currents Using Stacked Microbial Fuel Cells, Environmental Science \& Technology, 40, 10, (2006), 3388-3394 https://doi.org/10.1021/es0525511

[2] Mostafa Rahimnejad, Arash Adhami, Soheil Darvari, Alireza Zirepour, Sang-Eun Oh, Microbial fuel cell as new technology for bioelectricity generation: A review, Alexandria Engineering Journal, 54, 3, (2015), 745-756 https://doi.org/10.1016/j.aej.2015.03.031

[3] Taeyoung Kim, Sukwon Kang, Je Hoon Sung, Youn Koo Kang, Young Hwa Kim, Jae Kyung Jang, Characterization of polyester cloth as an alternative separator to Nafion membrane in microbial fuel cells for bioelectricity generation using swine wastewater, Journal of microbiology and biotechnology, 26, 12, (2016), 2171-2178 https://doi.org/10.4014/jmb.1608.08040 
[4] Jonathan Winfield, Iwona Gajda, John Greenman, Ioannis Ieropoulos, A review into the use of ceramics in microbial fuel cells, Bioresource Technology, 215, (2016), 296-303

https://doi.org/10.1016/j.biortech.2016.03.135

[5] Jonathan Winfield, John Greenman, David Huson, Ioannis Ieropoulos, Comparing terracotta and earthenware for multiple functionalities in microbial fuel cells, Bioprocess and Biosystems Engineering, 36, 12, (2013), 1913-1921 https://doi.org/10.1007/s00449-013-0967-6

[6] Andika Andika, Sudarlin Sudarlin, Pemanfaatan Gerabah dan Limbah Cair Tempe Sebagai Sumber Energi Alternatif Berbasis Microbial Fuel Cell, Jurnal Inovasi dan Pengelolaan Laboratorium, 2, 1, (2020), 44-50

[7] Anil N Ghadge, Mypati Sreemannarayana, Narcis Duteanu, Makarand $M$ Ghangrekar, Influence of ceramic separator's characteristics on microbial fuel cell performance, Journal of Electrochemical Science and Engineering , 4, 4, (2014), 315-326 https://doi.org/10.5599/jese.2014.0047

[8] Anil N. Ghadge, M. M. Ghangrekar, Development of low cost ceramic separator using mineral cation exchanger to enhance performance of microbial fuel cells, Electrochimica Acta, 166, (2015), 320-328 https://doi.org/10.1016/j.electacta.2015.03.105

[9] Faheem Uddin, Clays, Nanoclays, and Montmorillonite Minerals, Metallurgical and Materials Transactions A, 39, 12, (2008), 2804-2814 https://doi.org/10.1007/s11661-008-9603-5

[10] Xiaoyu Li, Kang Peng, $\mathrm{MoSe}_{2} /$ Montmorillonite Composite Nanosheets: Hydrothermal Synthesis, Structural Characteristics, and Enhanced Photocatalytic Activity, Minerals, 2018, 8, (2018), 268-278 https://doi.org/10.3390/min8070268

[11] Yayah Luthfiah, Pedy Artsanti, The Performance of Electricity Producing of Dual Chamber Microbial Fuel Cells (MFCs) Using Wastewater of Tempe Industries, International Conference on Science and Engineering, (2017)

[12] Muhammad Taufiq Hidayat, Irwan Nugraha, Kajian Kinerja Ca-Bentonit Kabupaten Pacitan-Jawa Timur Teraktivasi Asam Sulfat Sebagai Material Lepas Lambat (Slow Release Material) Pupuk Organik Urin Sapi, Indonesian Journal of Materials Chemistry, 1, 1, (2018), 27-37

[13] Chao Chen, Dong-Wha Park, Wha-Seung Ahn, $\mathrm{CO}_{2}$ capture using zeolite 13X prepared from bentonite, Applied Surface Science, 292, (2014), 63-67 https://doi.org/10.1016/j.apsusc.2013.11.064

[14] Charles Verdel, Nathan Niemi, Ben A. van der Pluijm, Variations in the Illite to Muscovite Transition Related to Metamorphic Conditions and Detrital Muscovite Content: Insight from the Paleozoic Passive Margin of the Southwestern United States, The Journal of Geology, 119, 4, (2011), 419-437 https://doi.org/10.1086/660086

[15] S. Ng, J. Plank, Interaction mechanisms between Na montmorillonite clay and MPEG-based polycarboxylate superplasticizers, Cement and Concrete Research, 42, 6, (2012), 847-854 https://doi.org/10.1016/j.cemconres.2012.03.005
[16] Suowei Wang, Yunhui Dong, Manli He, Lei Chen, Xianjin Yu, Characterization of GMZ bentonite and its application in the adsorption of $\mathrm{Pb}(\mathrm{II})$ from aqueous solutions, Applied Clay Science, 43, 2, (2009), 164-171 https://doi.org/10.1016/j.clay.2008.07.028

[17] Frederico Gil Alabarse, Rommulo Vieira Conceição, Naira Maria Balzaretti, Flávia Schenato, Ana Maria Xavier, In-situ FTIR analyses of bentonite under high-pressure, Applied Clay Science, 51, 1, (2011), 202-208 https://doi.org/10.1016/j.clay.2010.11.017

[18] M. I. Abdou, A. M. Al-sabagh, M. M. Dardir, Evaluation of Egyptian bentonite and nanobentonite as drilling mud, Egyptian Journal of Petroleum, 22, 1, (2013), 53-59 https://doi.org/10.1016/j.ejpe.2012.07.002

[19] J. D. Russell, A. R. Fraser, I.R. Spectroscopic Evidence for Interaction Between Hydronium ions and Lattice $\mathrm{OH}$ Groups in Montmorillonite, Clays and Clay Minerals, 19, 1, (1971), 55-59 https://doi.org/10.1346/CCMN.1971.0190106

[20]Ilmi Muftiana, Linda Suyati, Didik Setiyo Widodo, The Effect of $\mathrm{KMnO}_{4}$ and $\mathrm{K}_{3}\left[\mathrm{Fe}(\mathrm{CN})_{6}\right]$ Concentrations on Electrical Production in Fuel Cell Microbial System with Lactobacillus bulgaricus Bacteria in a Tofu Whey Substart, Jurnal Kimia Sains dan Aplikasi, $21,1,(2018), 49-53$ https://doi.org/10.14710/jksa.21.1.49-53

[21] Anthony J. Slate, Kathryn A. Whitehead, Dale A. C. Brownson, Craig E. Banks, Microbial fuel cells: An overview of current technology, Renewable and Sustainable Energy Reviews, 101, (2019), 60-81 https://doi.org/10.1016/j.rser.2018.09.044

[22]Tian Zhang, Changzheng Cui, Shengli Chen, Hanxi Yang, Ping Shen, The direct electrocatalysis of Escherichia coli through electroactivated excretion in microbial fuel cell, Electrochemistry Communications, 10, 2, (2008), 293-297 https://doi.org/10.1016/j.elecom.2007.12.009

[23]D. Permana, Djaenudin, Performance of Single Chamber Microbial Fuel Cell (SCMFC) for biological treatment of tofu wastewater, IOP Conference Series: Earth and Environmental Science, 277, (2019), 012008 https://doi.org/10.1088/1755-1315/277/1/012008

[24]Sampe Harahap, Pencemaran perairan akibat kadar amoniak yang tinggi dari limbah cair industri tempe, Jurnal Akuatika, 4, 2, (2013), 183-194

[25]Xiaoying Kong, Yongming Sun, Zhenhong Yuan, Dong $\mathrm{Li}$, Lianhua $\mathrm{Li}$, Yin $\mathrm{Li}$, Effect of cathode electron-receiver on the performance of microbial fuel cells, International Journal of Hydrogen Energy, 35, 13, (2010), 7224-7227 https://doi.org/10.1016/j.ijhydene.2010.03.106

[26]Farida Zulfah Fitriani, Linda Suyati, Wasino Hadi Rahmanto, Pengaruh Konsentrasi Substrat Maltosa terhadap Potensial Listrik Baterai Lactobacillus bulgaricus (MFC), Jurnal Kimia Sains dan Aplikasi, 20, 2, (2017), 74-78 https://doi.org/10.14710/jksa.20.2.74-78 